\title{
BENTUK KEHIDUPAN MANUSIA PRASEJARAH DI SITUS YOMOKHO \\ (Prehistoric living in the Yomokho Site)
}

Hari Suroto

Erlin N. Idje Djami

Balai Arkeologi Papua

Jalan Isele, Kampung Waena, Distrik Heram, Kota Jayapura 99358

e-mail: hariprimitiveart@gmail.com

INFO ARTIKEL

\section{Histori Artikel}

Diterima: 17 September 2018

Direvisi: 22 Oktober 2018

Disetujui: 5 November 2018

Keywords

Prehistory,

Yomokho Site,

Human life

Kata Kunci

Prasejarah,

Situs Yomokho,

Kehidupan manusia

\section{ABSTRACT}

Folklore that the Sentani people believe about the migration of their ancestors from Papua New Guinea who chose Yomokho Hill as an initial settlement, it is necessary to do research related to prehistoric human life forms on the Yomokho site. The purpose of this paper is to find out the prehistoric human life forms on the Yomokho Site. Methods of data collection are library studies, interviews, land surface surveys, excavations. Data analysis is artefactual analysis, contextual analysis, and XRD analysis. The prehistoric forms of human life on the Yomokho Site based on artifacts, ecophysics and the environmental context around the site indicate that they live hunting, fishing and gathering sago.

\section{ABSTRAK}

Cerita rakyat yang dipercaya Suku Sentani tentang migrasi nenek moyang mereka dari Papua New Guinea yang memilih Bukit Yomokho sebagai pemukiman awal, maka perlu dilakukan penelitian yang berkaitan dengan bentuk kehidupan manusia prasejarah di situs Yomokho. Tujuan penulisan ini untuk mengetahui bentuk kehidupan manusia prasejarah di Situs Yomokho. Metode pengumpulan data yaitu studi pustaka, wawancara, survei permukaan tanah, ekskavasi. Analisis data yaitu analisis artefaktual, analisis kontekstual, dan analisis XRD. Bentuk kehidupan manusia prasejarah di Situs Yomokho berdasarkan artefak, ekofak serta konteks lingkungan sekitar situs menunjukkan bahwa mereka hidup berburu, mencari ikan dan meramu sagu.

\section{PENDAHULUAN}

Balai Arkeologi Jayapura pada tahun 2010 melakukan eksplorasi arkeologi prasejarah di Kawasan Danau Sentani, dalam penelitian ini berhasil menemukan situs-situs arkeologi maupun artefak yang disimpan masyarakat. Situs-situs arkeologi yang berhasil ditemukan yaitu Yomokho, Marweri Urang, Mantai, Gua Rukhabulu Awabhu, Jayapura melakukan ekskavasi di Situs Ceruk Reugable dan Ceruk Ifeli-feli. Survei Yomokho, bertujuan untuk memperoleh permukaan yang dilakukan di Situs Yomokho, ditemukan lapisan konsentrasi cangkang moluska di lereng bukit bagian timur. Artefak yang disimpan oleh masyarakat yaitu gerabah, manik-manik, gelang batu, kapak batu dan kapak perunggu (Tim penelitian, 2010).

\section{Pada tahun 2011 Balai Arkeologi}


gambaran jumlah dan keragaman tinggalan, kedalaman lapisan budaya dan jenis lapisan tanah. Pembukaan kotak test pit dilakukan satu di puncak bukit dan satu di lereng bukit bagian timur. Hasil ekskavasi di lereng Bukit Yomokho diperoleh temuan berupa pecahan gerabah hias maupun polos, manik-manik, cangkang moluska laut, cangkang moluska danau, arang, tulang binatang, dan tulang manusia.

Selain ekskavasi di Situs Yomokho, pada tahun yang sama juga dilakukan eksplorasi arkeologi pada beberapa lokasi di Kawasan Danau Sentani yang belum terjangkau penelitian sebelumnya. Eksplorasi ini berhasil menemukan situs megalitik di Kampung Ayapo Baru dan situs hunian yaitu situs Phulende di Kampung Ifar besar dan situs Kampung tua Abar (Suroto et. al., 2011). Pada tahun 2012 Balai Arkeologi Jayapura melakukan penelitian di Situs Yomokho untuk mengetahui strategi pemilihan tempat tinggal dan strategi subsistensi manusia pendukung budaya Situs Yomokho (Suroto et. al., 2012).

Upaya untuk merekonstruksi sejarah kebudayaan, rekonstruksi cara-cara hidup, dan penggambaran proses budaya masa lampau (Binford, 1972:78) hendaknya memperhatikan tiga dimensi penting yaitu bentuk, ruang dan waktu. Ketiga dimensi tersebut saling terkait satu dengan yang lainnya dan merupakan dimensi yang harus mendapatkan perhatian para arkeolog.
Dimensi kerap digunakan sebagai landasan untuk memberikan waktu, fungsi, sosial ekonomi, religi, dan hal lainnya dari kehidupan masa lalu. Begitu juga sebaliknya dimensi ruang data memberikan informasi akan fungsi, waktu, sebaran, dan hal lainnya dari bentuk artefak yang ditemukan. Dimensi waktu, memberikan gambaran kapan sebuah artefak atau kehidupan masa lalu berlangsung.

Secara umum, situs-situs arkeologi dapat diklasifikasi menjadi dua tipe, yaitu stratified sites dan surface sites. Stratified sites adalah situs-situs yang secara geologik berada dalam konteks langsung, sedang surface sites adalah situs-situs yang berada di atas permukaan tanah, tanpa konteks geologik. Kedua tipe situs ini dapat diklasifikasi dalam berbagai cara. Berdasarkan fungsi dan jenis aktivitasnya, situs-situs arkeologi dapat dibedakan menjadi: situs hunian, situs perdagangan, situs penambangan, situs penguburan, situs seremonial dan situs perbengkelan (Hole dan Heizer, 1973; Sharer dan Ashmore, 1979: 68100).

Butzer (1964) menyatakan bahwa kondisi lingkungan dapat dianggap sebagai salah satu faktor penentu dalam pemilihan tempat hunian. Beberapa variabel yang berhubungan dengan kondisi lingkungan tersebut diantaranya: tersedia kebutuhan akan air; tersedianya fasilitas-fasilitas yang diperlukan untuk bergerak lebih mudah 
(pantai, sungai, rawa dan hutan); dan tersedianya sumber makanan baik flora dan fauna, serta faktor-faktor kemudahan memperoleh makanan.

Dalam upaya mempertahankan eksistensinya, manusia memerlukan tempat untuk berinteraksi dengan sesamanya maupun dengan lingkungannya. Makanan diperlukan dalam upaya mempertahankan hidupnya. Sehingga pemilihan tempat hunian dan jenis makanan dapat dipandang sebagai indikasi strategi adaptasi manusia pada masa lampau (Wiradnyana, 2011:60). Proses adaptasi sendiri berjalan ketika manusia membandingkan pola tingkah laku yang telah dilakukannya dengan kondisi lingkungan yang dihadapi untuk kemudian disesuaikan.

Situs sebagai sumber data dalam arkeologi merupakan rangkaian ekosistem manusia dan lingkungannya, sehingga dalam pemilihan tempat tinggal selain didasarkan pada kondisi lingkungan juga bentang alam. Sejalan dengan hubungan antara manusia dengan alam lingkungannya, Subroto (1985:1178) mengemukakan bahwa adanya hubungan antara pola pemukiman dengan gejala-gejala geografis seperti halnya keadaan topografis, tanah, vegetasi, dan zona curah hujan.

Terkait dengan cerita rakyat yang dipercaya Suku Sentani tentang migrasi nenek moyang mereka yang memilih Bukti Yomokho, Pulau Ajauw dan Pulau Kwadeware sebagai pemukiman awal, maka perlu dilakukan penelitian yang berkaitan dengan hunian awal prasejarah di Situs Yomokho. Tulisan ini akan membahas tentang bentuk kehidupan prasejarah di Situs Yomokho.

Dalam penulisan ini dilakukan dengan pengumpulan data, analisis data dan interpretasi data. Menurut Deetz (1967:6) ada tiga tingkatan dalam penelitian arkeologi yaitu observasi (observation) merupakan tingkat pengumpulan data, deskripsi (description) yaitu tingkat pengolahan data dan penjelasan (explanation) adalah tingkat interpretasi data.

\section{PEMBAHASAN}

Situs Yomokho terletak sekitar 200 meter sebelah barat Khalkote, lokasi Festival Danau Sentani. Survei permukaan tanah di Situs Yomokho, dilakukan dengan mengamati permukaan puncak bukit, lereng bukit, kaki bukit maupun di lingkungan sekitar. Seluruh permukaan Bukit Yomokho ditumbuhi rumput ilalang, sebagian lereng bukit sebelah timur dimanfaatkan untuk berkebun umbi jalar dan ketela pohon sedangkan kaki bukit berbatasan dengan hutan sagu.

Pecahan gerabah ditemukan di puncak bukit, lereng bukit, kaki bukit dan kebun. Pecahan gerabah yang ditemukan di puncak bukit sangat sedikit, pecahan gerabah lebih banyak ditemukan di kaki bukit. Cangkang siput danau Melanoides 
tuberkulata, moluska laut Verenidae serta bagian timur dan selatan. tulang manusia ditemukan di lereng bukit

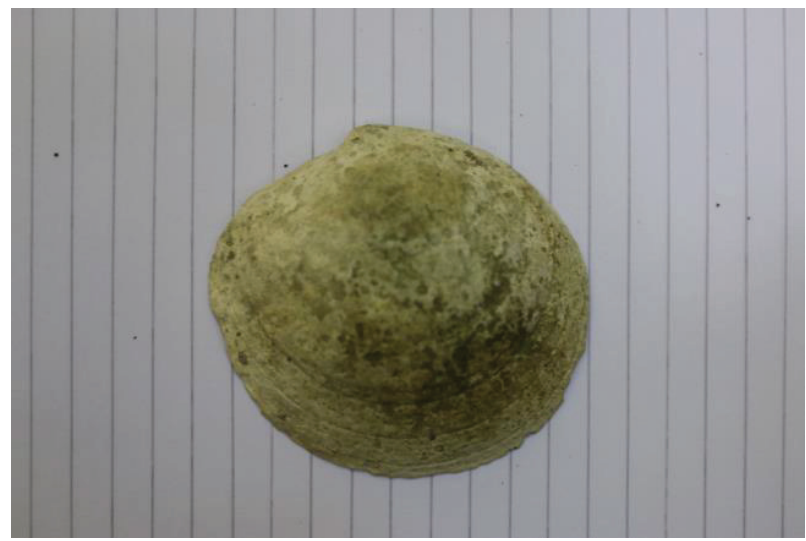

Gambar 1. Cangkang moluska laut Verenidae (dokumentasi Balar Papua)

Sepanjang puncak Bukit Yomokho Sebagian susunan batu tertata dari puncak terdapat susunan batu dengan lebar $100-190$ bukit ke arah lereng. Menurut informasi dari $\mathrm{cm}$, tertata rapi dengan orientasi timur laut- masyarakat Asei, pada masa lalu susunan barat daya, berukuran panjang $107,4 \mathrm{~m}$. batu tersebut merupakan batas-batas kebun.

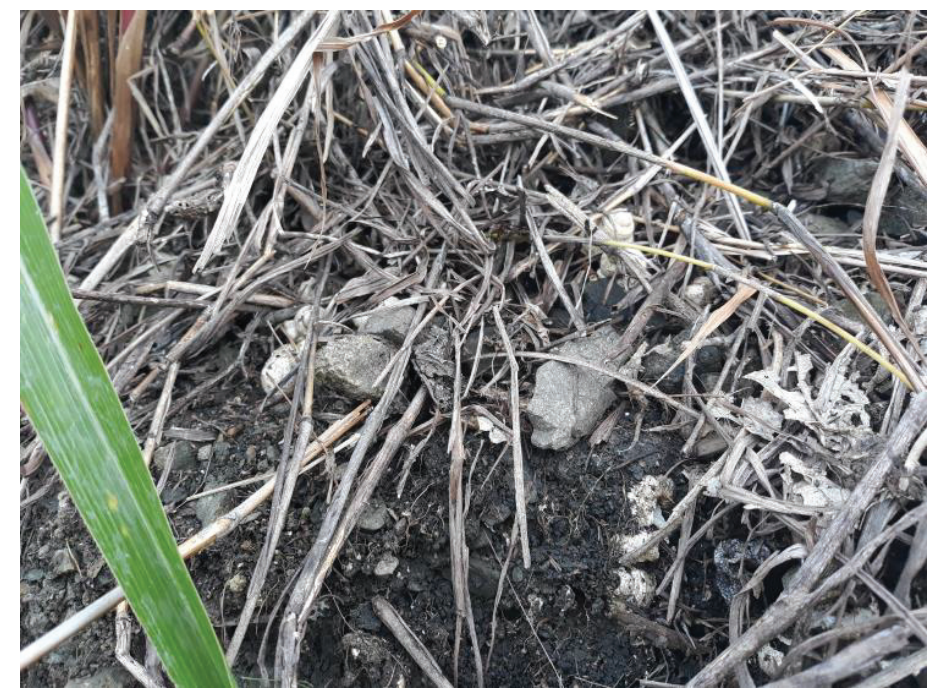

Gambar 2. Cangkang siput danau (Melanoides tuberkulata) temuan permukaan 


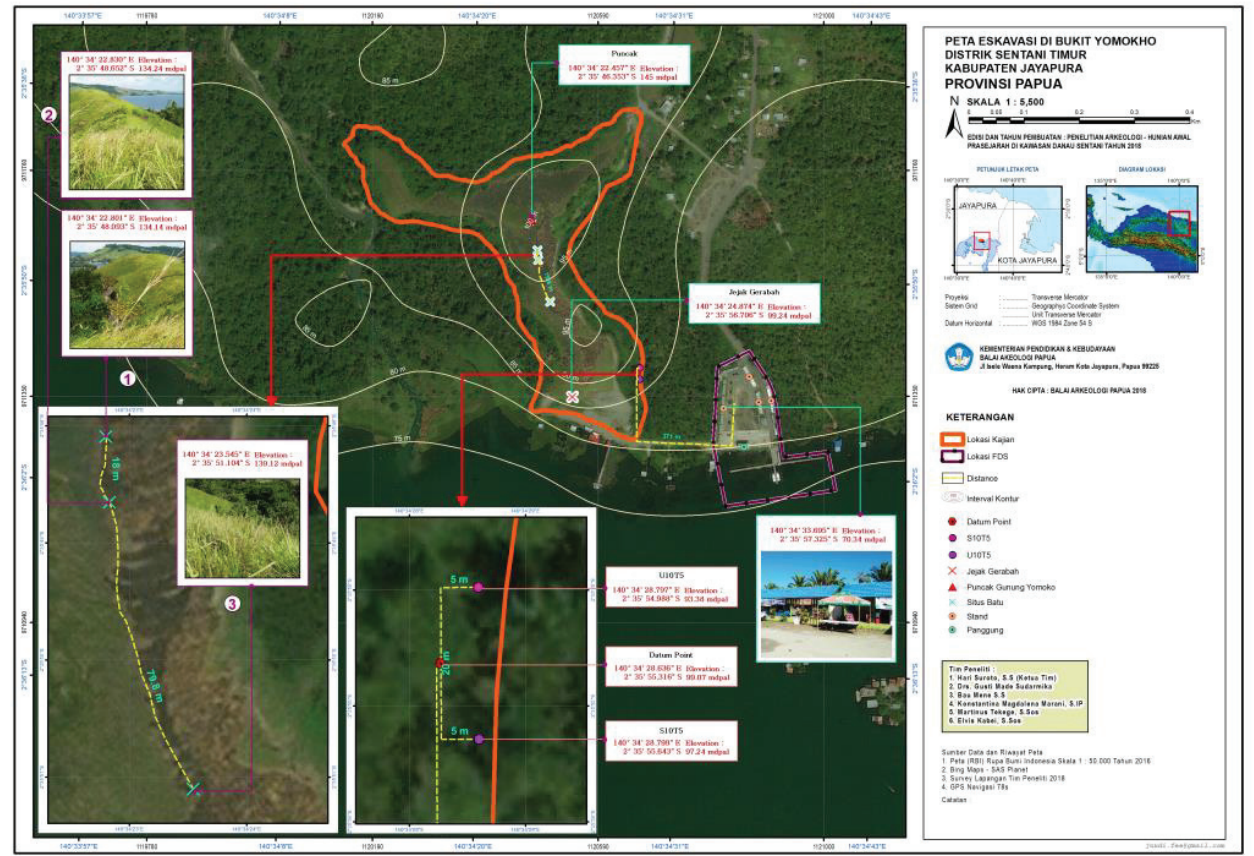

Peta 1. Situs Yomokho

Analisis terhadap fragmen gerabah dari Situs Yomokho, berdasarkan pengamatan terhadap bentuk tepian, badan dan dasar diketahui bentuk utuh wadah adalah periuk dan tempayan. Periuk memiliki diameter mulut lebih kecil dari tempayan. Gerabah jenis tempayan memiliki dinding yang dicampur dengan pasir kasar. yang lebih tebal daripada periuk.

Analisis teknik pembuatan gerabah jenis periuk dari situs Yomokho, diketahui dilakukan dengan mengamati jejak dibuat dengan teknik roda putar, hal ini pembentuk permukaan bagian luar atau terlihat permukaan gerabah terdapat jejak bagian dalam. Analisis teknik pembuatan bekas striasi yang lurus dan rapi, hal ini gerabah jenis tempayan dari Situs Yomokho menunjukan gerabah dibuat dengan teknik berdinding tebal, jejak-jejak pembuatan pada roda putar cepat. Pada akhir pembuatan permukaan dalam gerabah berupa cekungan sebelum proses pembakaran diupam terlebih yang cukup besar dan pada permukaan luar dahulu, ini terlihat dari permukaan dinding berupa bekas pemukul yang menunjukan yang halus dan tidak berpori. Proses teknik tatap pelandas.
Analisis teknik pembuatan gerabah

Warna bagian permukaan terdiri atas merah, coklat dan hitam. Pengamatan pada penampang lintang fragmen gerabah yang mengindikasikan dibakar di tempat terbuka (open fire). Gerabah ini dibuat dari tanah liat pembakaran gerabah dilakukan di tempat 
terbuka. Periuk ini dibuat dari tanah liat yang dicampur dengan pasir halus.

Fungsi gerabah Situs Yomokho dapat diketahui dari bentuk, jejak pakai dan Untuk mengetahui asal usul gerabah situs konteksnya. Gerabah jenis periuk Yomokho apakah asal usulnya dari Kampung mengindikasikan untuk memasak, hal ini Abar maka dilakukan analisis XRD. Hasil terlihat bekas jejak pakai berupa jelaga, analisis XRD menunjukkan unsur mineral selain itu gerabah jenis ini memiliki konteks pada gerabah Situs Yomokho dan gerabah

temuan arang. Dinding periuk yang tipis Kampung Abar berbeda.

mempercepat proses pemanasan makanan.

Gerabah jenis tempayan digunakan untuk menyimpan bahan makanan dan air. Ukuran tempayan lebih besar daripada periuk, dan dinding gerabah jenis tempayan lebih tebal daripada periuk. Dinding yang tebal membuat tempayan kuat untuk menyimpan bahan makanan atau air dalam volume banyak.
Saat ini gerabah tradisional masih diproduksi oleh masyarakat Kampung Abar, Distrik Ebungfauw, Kabupaten Jayapura. 


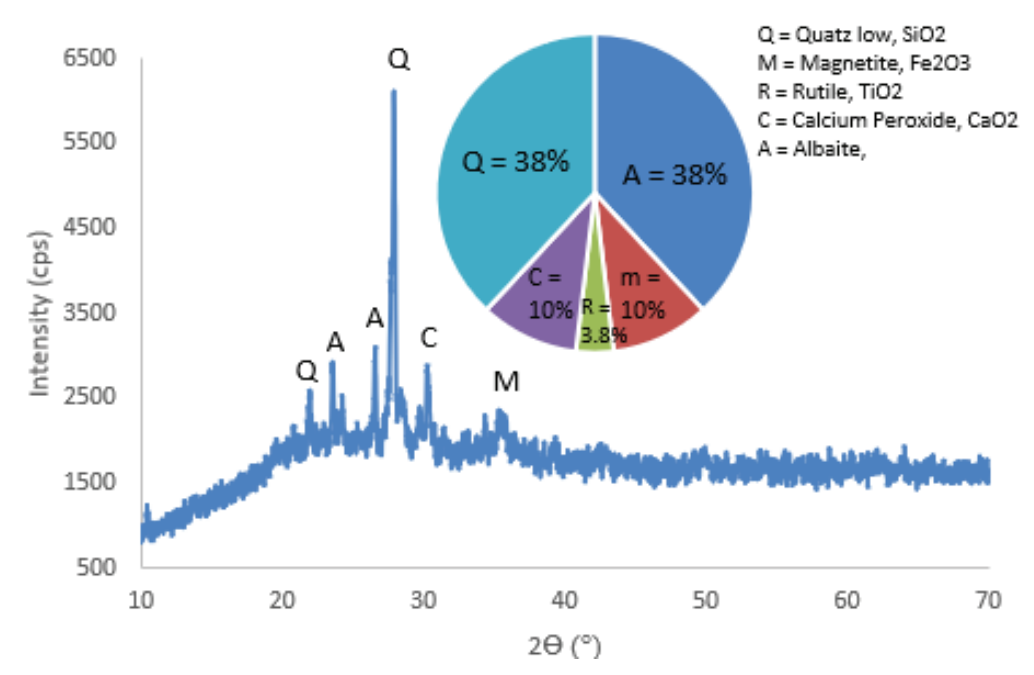

Gambar 4. Hasil analisis XRD gerabah Yomokho

Hal ini menunjukkan bahwa gerabah Situs Yomokho bukan berasal dari Kampung Abar. Kemungkinan gerabah Situs Yomokho berasal dari luar Danau Sentani atau bisa juga manusia prasejarah di Situs Yomokho mampu membuat sendiri. Hal ini perlu dilakukan penelitian lanjutan.

Ekofak yang ditemukan dalam survei permukaan tanah di Situs Yomokho yaitu cangkang siput danau Melanoides, cangkang moluska laut Verenidae, tulang binatang, gigi babi dan tulang manusia. Kondisi cangkang siput danau yang utuh, menunjukkan proses pengolahannya yaitu dengan cara direbus. Hal ini didukung oleh konteks temuan lok pecahan gerabah dan arang. Ekofak yang per ditemukan dalam ekskavasi Kotak U10T5 spit 8 berupa gigi babi. Babi di Papua saat ini dikenal sebagai jenis Sus Scrofa Papuensis.

Untuk mengetahui bentuk kehidupan masa lalu di Situs Yomokho dilakukan dengan mengaitkan konteks artefak dengan lingkungan. Situs Yomokho menggambarkan adaptasi manusia terhadap lingkungan. Pemilihan lokasi sebagai hunian berkaitan dengan keberadaan Danau Sentani yang menghasilkan sumber makanan diantaranya moluska dan ikan, selain itu Danau Sentani juga merupakan sumber air bersih.

Berdasarkan hasil survei permukaan tanah dan ekskavasi di Situs Yomokho, diketahui temuan artefak gerabah lebih banyak ditemukan di kaki bukit. Hal ini menunjukkan bahwa manusia prasejarah Situs Yomokho memilih kaki bukit sebagai lokasi hunian, hal ini didasarkan pada kondisi permukaan kaki bukit yang datar.

Menurut Kal Muller (2008) dan Peter Bellwood (1978) tidak ada data ilmiah yang membuktikan keberadaan babi di Papua sebelum 4000 tahun yang lalu. Walaupun belum ada waktu pasti tentang kapan pertama 
kali babi masuk ke dataran tinggi Papua, dan Gua Taora di Vanimo Papua Nugini. tetap bisa dipastikan bahwa babi (bersama- Gorecki (1996) menyatakan bahwa gerabah sama dengan anjing dan ayam) dibawa dari Gua Lachitu dan Gua Taora memiliki masuk ke Papua oleh penutur Austronesia pertanggalan 5400 tahun yang lalu, tetapi pada 1500 hingga 1000 SM. Berdasarkan beberapa peneliti menyangsikan pertanggalan teori Muller dan Bellwood ini maka yang dilakukan Gorecki dan mereka percaya diperkirakan babi yang ditemukan dalam pertanggalannya lebih muda (Simanjuntak, ekskavasi di Situs Yomokho berasal dari 1997:944). Jika dikaitkan dengan cerita 1500 - 1000 SM, sedangkan hasil dating C- rakyat yang dipercaya masyarakat Sentani 14 terhadap sampel arang hasil ekskavasi terkait asal usul nenek moyang mereka yang tahun 2011 di lereng Bukit Yomokho berasal dari timur yaitu Papua Nugini, tentu mengindikasikan manusia pernah beraktivitas saja temuan artefak gerabah hias dari Situs di situs ini $2590 \pm 120 \mathrm{BP}$.

Yomokho mungkin saja memiliki kaitan.

\section{Hasil ekskavasi di kaki Bukit} Yomokho menunjukkan bahwa temuan pecahan gerabah lebih banyak daripada di lereng bukit maupun puncak bukit. Hal ini menunjukkan bahwa hunian manusia masa lalu di Situs Yomokho berada di kaki bukit. Diperkirakan mereka tinggal dalam rumah panggung, walaupun bukti tiang-tiang rumah belum ditemukan.

Berdasarkan tulang manusia yang lebih banyak ditemukan di lereng bukit, maka diperkirakan lereng Bukit Yomokho merupakan tempat penguburan. Hal ini pesisir.

berdasarkan ekskavasi tahun 2011 di lereng

Bukit Yomokho menemukan tengkorak dan tulang manusia dengan konteks temuan

\section{PENUTUP}

pecahan gerabah, maka diperkirakan gerabah dijadikan sebagai bekal kubur.

Latarbelakang pemilihan lokasi hunian awal prasejarah di Kawasan Danau Sentani berkaitan dengan keberadaan Danau

Berdasarkan analisis terhadap motif Sentani yang menghasilkan sumber makanan hias gerabah dari Situs Yomokho memiliki diantaranya moluska dan ikan, selain itu kesamaan dengan gerabah dari Gua Lachitu Danau Sentani juga merupakan sumber air 
bersih. Dengan mengacu pada hasil temuan arkeologi pada situs Yomokho menggambarkan bahwa bentuk kehidupan manusia pendukung situs hunian awal prasejarah di situs Yomokho termasuk dalam budaya neolitik.

Bentuk kehidupan manusia prasejarah di Situs Yomokho berdasarkan artefak, ekofak serta konteks lingkungan sekitar situs menunjukkan bahwa mereka hidup berburu, mencari ikan dan meramu sagu. Selain itu berdasarkan temuan cangkang moluska laut menunjukkan daya jelajah mencari makanan hingga pesisir laut.

\section{DAFTAR PUSTAKA}

Bellwood, Peter. 1978. Man Conquest of the Pacific. The Prehistory of South East Asia and Oceania. Auckland: William Collins Publisher Ltd.

Binford, Lewis R. 1972. Archaeological Perspective. New York: Seminar Press.

Butzer, K. W. 1964. Environment and Archaeology. London: Methuen.

Deetz, James. 1967. Invitation to Archaeology. New York: The Natural History Press.

Gorecki, P. 1996. Early Pottery from Two Rockshelter near Vanimo, Papua New Guinea: Some Stratigraphic and Chronological Considerations. Conference on the Western Pacific, 5000 to 2000 Before Present. Vanuatu National Museum - Australian National University - ORSTOM. Port Villa, Vanuatu.

Hole, Frank dan Robert F. Heizer. 1973. An Introduction to Prehistoric Archaeology third edition. New York: Holt, Rinehart and Winston, Inc.

Muller, Kal. 2008. Introducing Papua. Daisy World Books.

Sharer, Robert J. dan Wendy Ashmore. 1979. Fundamentals of Archaeology. California: The Benjamin/ Cummings Publishing Company, Inc.

Simanjuntak, Harry Truman. 1997. "Revieuw of the prehistory of Irian Jaya" dalam Perspectives on the Bird's Head of Irian Jaya, Indonesia (Jelle Miedema, Cecilia Ode dan Rien A.C. Dam eds.). Proceedings of the Conference Leiden, 13-17 October 1997. Hlm. 941-950.

Subroto, P. H. 1985. Studi tentang Pola Pemukiman Arkeologi Kemungkinan-Kemungkinan Penerapannya di Indonesia. PIA III. Jakarta: Pusat Penelitian Arkeologi Nasional.

Suroto, Hari, Erlin N. I. Djami, M. Irfan Mahmud. 2011. Ekskavasi dan Survei Arkeologi di Kawasan Danau Sentani. Laporan Penelitian Balai Arkeologi Jayapura.

Suroto, Hari, Klementin Fairyo, Amurwani Putri. 2012. Penelitian Arkeologi di Kawasan Danau Sentani. Laporan Penelitian Balai Arkeologi Jayapura.

Tim Penelitian. 2010. Penelitian Arkeologi di Kawasan Danau Sentani. Laporan Penelitian Balai Arkeologi Jayapura.

Wiradnyana, Ketut. Prasejarah: Sumatera Bagian Utara Kontribusinya pada Kebudayaan Kini. Jakarta: Yayasan Pustaka Obor Indonesia. 